\title{
FAKTOR-FAKTOR PEMILIHAN PAKET WISATA KINTAMANI-MONKEY FOREST TOUR OLEH WISATAWAN MANCANEGARA (STUDI KASUS BIRO PERJALANAN WISATA DESTINATION ASIA)
}

\author{
Gede Eka Sucita Darma \\ I GPB. Sasrawan Mananda \\ Ni Putu Eka Mahadewi \\ Email : ekasucitaipw@ymail.com \\ PS. S1 Industri Perjalanan Wisata \\ Fakultas Pariwisata UNUD
}

\begin{abstract}
ABSTRAK
Penelitian ini membahas tentang analisis faktor yang mempengaruhi pemilihan paket KintamaniMonkey Forest Tour oleh wisatawan. Penelitian ini bertujuan untuk mengetahui faktor - faktor yang mempengaruhi pemilihan paket Kintamani - Monkey Forest Tour oleh wisatawan mancanegara. Metode penelitian yang digunakan dalam penelitian ini adalah penelitian kuantitatif dengan menyebarkan 210 kuesioner kepada wisatawan yang menggunakan paket wisata Kintamani - Monkey Forest Tour, dan wawancara terstruktur dengan Operational Manager dan The Chief of Destination Asia Guide Assotiation. Teknik analisis data dalam penelitian ini adalah Analisis Faktor. Hasil penelitian ini menunjukkan ada lima faktor yang paling mempengaruhi pemilihan paket wisata Kintamani - Monkey forest Tour oleh wisatawan mancanegara yang menggunakan jasa Biro Perjalanan Wisata Destination Asia. Lima faktor tersebut yaitu harga, icon paket wisata, transportasi, tampilan brosur, penampilan pramuwisata. Berdasakan hasil penelitian tersebut, maka dapat disarankan bagi Destination Asia dengan memperhatikan faktor - faktor yang terbentuk tersebut hendaknya bisa menjadikan hasil penelitian ini sebagai sebuah acuan dan pertimbangan dalam hal baik perbaikan sebuah paket wisata yang telah ada maupun untuk membuat sebuah paket wisata yang baru. Hasil penelitian ini juga diharapkan dapat menjadi acuan bagi akademisi untuk melakukan penelitian lanjutan dan peneltian-penelitian lainnya yang relevan dengan penelitian ini.
\end{abstract}

Kata Kunci : Analisis Faktor, Paket Wisata, Wisatawan, Biro Perjalanan Wisata.

\section{PENDAHULUAN}

Bali merupakan daerah tujuan wisata yang sudah terkenal sampai ke mancanegara. Bali yang juga dikenal dengan nama Pulau Dewata, Pulau Seribu Pura sangat mendukung dengan adanya kegiatan pariwisata. Kekayaan adat istiadat, budaya dan alam yang indah dan eksotis menjadi daya tarik bagi ribuan wisatawan baik wisatawan mancanegara maupun domestik. Bali menjadi daya tarik wisata yang sangat diminati wisatawan karena memiliki semua unsur - unsur pokok yang harus dimiliki sebuah daerah tujuan wisata yaitu: (1) Daya tarik wisata, (2) Prasarana Wisata, (3) Sarana Wisata, (4) Tata laksana/infrastruktur,(5) Masyarakat/lingkungan (Suwena, $2010: 83$ )

Seperti lapangan usaha pada umumnya, pariwisata juga mengalami pasang surut dalam perjalanannya. perekonomian Bali seakan lumpuh ketika Bali tertimpa musibah bom kemudian memberikan dampak yang sangat besar terhadap kepariwisataan Bali yang menyebabkan 
Bali sangat terpuruk kala itu. Menyimak perjalanan kepariwisataan Bali tersebut serta memperhatikan jumlah kunjungan wisatawan mancanegara yang terus meningkat menunjukkan bahwa Bali mulai bergerak kearah pemulihan mulai terlihat sejak tahun 2007 dan kedepannya terus meningkat secara signifikan sampai dengan tahun 2013. Peningkatan secara terus menerus ini menunjukkan semakin tingginya kepercayaan dunia internasional akan situasi Bali (Bali Toursm Statistic, 2013 : 18)

Berdasarkan data yang diperoleh dari Dinas Pariwisata Bali menunjukkan bahwa tingkat kunjungan wisatawan mancanegara ke Bali fluktuatif. Pada tahun 2010 jumlah wisatawan mancanegara yang datang sebanyak 2.493.058 orang dan pada tahun 2011 mengalami peningkatan menjadi 2.756 .579 dengan pertumbuhan sebesar 10,57\%, peningkatan jumlah kunjungan ini terus terjadi selama lima tahun terkhir ini.

Namun apabila dilihat berdasarkan pertumbuhannya, pernah mengalami penurunan pada tahun 2012 hal ini terjadi selain karena faktor yang berasal dari Negara-negara yang bersangkutan ada juga beberapa penyebab yang berasal dari internal Bali sendiri. Beberapa faktor internal Bali yang dimaksud adalah adanya isu rabies dan flu burung, kemacetan, kotor karena sampah, kriminalitas dan sebagainya. Kondisi ini yang membuat wisatawaan ke Bali kurang aman yang nyaman. Hal ini menjadi perhatian serius pemerintah Bali dan industri pariwisata yang ada di Bali.

Menurut data yang diperoleh dari Dinas Pariwisata Provinsi Bali jumlah Biro Perjalanan Wisata pada tahun 2014 mencapai 365 Biro Perjalanan Wisata. Salah satu Biro Perjalanan Wisata itu adalah Destination Asia yang terletak di Jl. By Pass Ngurah Rai No.360 Sanur Bali. Biro Perjalanan Wisata ini mempunyai target pasar wisatawan Australia. Biro perjalan wisata Destination Asia memiliki berbagai macam paket wisata, namun ada satu paket wisata yang paling diminati oleh wisatawan yang menggunaka jasa biro perjalanan wisata Destination Asia, paket wisata itu adalah paket wisata Kintamani - Monkey Forest Tour. Penjualan paket wisata ini mencapai 300 paket wisata per bulannya, jumlah ini jauh lebih tinggi dibandingkan dengan paket wisata lainnya yang dimiliki biro perjalanan wisata Destination Asia. Melihat fenomena ini maka perlu dilakukan sebuah penelitian untuk menjawab sebuah rumusan masalah mengenai faktor-faktor pemilihan paket wisata Kintamani - Monkey Forest Tour untuk mengetahui faktor - faktor apa saja yang menyebabkan wisatawan sangat berminat memilih paket wisata ini.

Penelitian ini dilakukan dengan melihat unsur internal dari paket wisata Monkey - Forest Tour. Unsur-unsur dasar ini nantinya di jabarkan kembali membentuk variabel-variabel yang di analisis menggunakan analisis faktor. Hasil analisis nantinya membentuk beberapa faktor, faktor-faktor yang terbentuk merupakan faktorfaktor yang menyebabkan paket wisata Kintamani - Monkey Forest Tour menjadi sangat diminati oleh wisatawan mancanegara yang menggunakan jasa Biro Perjalanan Wisata Destination Asia.

Faktor-faktor yang terbentuk inilah yang diharapkan dapat digunakan sebagai acuan dalam memperbaharui ataupun membuat paketpaket wisata yang baru dengan harapan dapat diminati juga oleh wistawan mancanegara yang menggunakan jasa biro perjalanan Destination Asia. Maka dari itu diperlukan penelitian lebih lanjut untuk mengetahui faktor-faktor yang menyebabkan paket wisata Kintamani-Monkey Forest Tour sangat diminati oleh wisatawan mancanegara yang menggunakan jasa Biro Perjalanan Wisata Destination Asia.

\section{METODE}

Dalam penelitian ini menggunakan 21 variabel faktor sebagai indikator penelitian yang kemudian dianalisis menggunakan analisis faktor seta menggunakan dua jenis data yaitu kualitatif dan kuantitaif. Sumber data berupa data primer yang diperoleh dari data - data hasil wawancara dan kuesioner yang telah disebarkan kepada wisatawan yang sedang menggunakan paket Kintamani - Monkey Forest Tour dan data sekunder yang dalam penelitian ini adalah dokumentasi - dokumentasi selama penelitian, data - data pendukung dari Dinas Pariwisata Provinsi Bali, situs internet, tinjauan penelitian sebelumnya dan lain - lain.

Penelitian ini menggunakan teknik purposive sampling, yaitu pada cara ini siapa yang diambil sebagai anggota sampel diserahkan 
pada pertimbangan pengumpul data yang berdasarkan atas pertimbangangnya sesuai dengan maksud dan tujuan penelitian (Sukandarrumidi, 2006 : 65). Sampel dalam penelitian ini adalah wisatawan yang menggunakan jasa biro perjalanan wisata Destination Asia. Jumlah sampel yang digunakan dalam penelitian ini adalah 210 sampel.

Penentuan besarnya sampel dalam penelitian ini didasarkan pada pendapat J.Supranto (dalam Widyasrama, 2014) bahwa untuk memperoleh hasil yang baik, maka banyaknya responden yang diambil untuk menjawab kuisioner adalah sebanyak 5 kali atau 10 kali dari variabel yang di muat dalam kuisioner. Berdasarkan konsep tersebut di atas, jumlah sampel berdasarkan jumlah variabel $\mathrm{x}$ (dikali) 10 , jadi sampel yang ditetapkan oleh peneliti sebanyak 210 sampel. Teknik analisis data yang diganakan dalam penelitian ini adalah teknik analisis kuantitatif. Adapun tenik analisis data yang digunakan adalah Analisis pengujian istrumen penelitian. dan Analisis faktor

\section{HASIL DAN PEMBAHASAN}

Dalam penelitian ini menggunakan 210 wisatawan yang menggunakan paket wisata Kintamani - Monkey Forest Tour sebagai responden, responden dalam penelitian ini di dominasi oleh wisatawan dengan latar belakang pekerjan sebagai karyawan dengan jumlah 54 orang, sedangkan responden dengan dominasi rendah adalah wisatawan dengan latar belakang pekerjaan sebagai dosen dan militer masingmasing 2 dan 5 orang.

Berdasarkan data yang diperoleh dari 210 responden tersebut kemudian di analisis menggunakan analisis faktor dengan bantuan program SPSS 18.0.0. Pada tahap pertama dalam analisis faktor adalah uji interpedensi, dimana pada tahap ini ditemukan bahwa nilai KMO mencapai 0,796 dengan signifikasi 0,000 yang berarti analisis ini dapat dilanjutkan ke tahap selanjutnya. Pada tahap selanjutnya akan muncul tabel MSA dimana pada tahap ini akan ditampilkan semua indikator bersama nilai loadingnya, dan indikator dengan nilai loading dibawah 0,5 harus dikeluarkan dari analisis, hal ini terus dilakuakan berulang kali hingga tidak ada lagi indikator dengan nilai dibawah 0,5
Selanjutnya akan muncul tabel communalities, eigen values, dan component matrix, untuk kemudian hasil pada component matrik ini di rotasi untuk mendapatkan rotated component matrix. Berdasarkan tabel rotated component matrix kemudian diketahui terbentuk lima faktor dengan masing-masing indikator pembentuk di setiap faktor. Hasil dari analisis faktor menemukan bahwa ada lima faktor yang membuat paket wisata Kintamani-Monkey Forest Tour sangat diminati wisatawan, faktor - faktor tersebut diantaranya :

1. Faktor Harga terdiri dari variabel variasi obyek $(0,658)$, waktu yang ditawarkan $(0,651)$, harga yang ditawarkan $(0,594)$, harga termasuk tiket masuk $(0,714)$, harga termasuk asuransi $(0,531)$, harga termasuk snack $(0,627)$, harga termasuk makan siang $(0,819)$, desain brosur $(0,596)$, terdapat peta pada brosur $(0,731)$, dan informasi yang lengkap pada brosur $(0,733)$.

2. Faktor Icon Paket Wisata terdiri dari variabel kecakapan pramuwisata $(0,860)$, dan icon paket berupa gambar Gunung Batur $(0,842)$.

3. Faktor Transportation terdiri dari variabel kendaraan sesuai yang diinginkan (0,693), penjemputan ke hotel $(0,624)$, dan tempat makan siang yang menarik $(0,743)$.

4. Faktor Tampilan Brosur terdiri dari variabel brosur memiliki warna yang menarik $(0,783)$, dan gambar depan brosur menarik $(0,694)$.

5. Faktor Penampilan Pramuwisata terdiri dari variabel penampilan pramuwisata $(0,852)$

Wisatawan dalam menentukan pilihannya terhadap sebuah paket wisata sangat memperhatikan harga paket wisata yang ditawarkan untuk paket wisata tersebut, apabila dalam kesatuan harga ini sudah mencangkup banyak aspek yang dirasakan sangat menguntungkan bagi 
wisatawan maka wisatawan tidak akan ragu dalam memilih paket wisata tersebut.

Wisatawan dalam mengambil sebuah keputusan untuk memilih sebuah paket wisata akan sangat dipengaruhi oleh icon dari paket wisata itu yang berupa gambar yang diperihatkan di brosur paket wisata, hal ini terjadi karena wisatawan tertarik untuk datang berkunjung ke tempat yang di tampilkan pada suatu brosur paket wisata, maka dari itu pemilihan tampilan atau daya tarik wisata yang ada di dalam paket wisata itu sebagai icon dapat dipilih dengan memilih daya tarik wisata yang terkenal agar wisatawan tertarik untuk memilih paket wisata tersebut.

Bagi wisatawan jenis transportasi yang ditawarkan menjadi hal yang perlu dipertimbangkan apalagi jika jenis paket wisata tersebut merupakan Full Day Tour maka wisatawan menginginkan tranportasi yang nyaman agar selama dalam perjalanan wisatawan tidak merasa terganggu dengan kondisi perjalanan seperti jalan rusak, cuaca yang panas dll.

Wisatawan dalam mengambil sebuah keputusan untuk membeli sebuah paket wisata ternyata benar sangat dipengaruhi oleh desain brosur itu sendiri, melalui penelitian inipun terungkap bahwa warna dasar brosur serta gambar yang ditampilan pada halaman depan brosur yang menarik dapat menarik minat wisatawan untuk memilih paket wisata tersebut.

Setidaknya dengan warna yang menarik sebuah paket wisata memiliki daya tarik yang lebih dibandingkan dengan paket wisata lainnya yang memiliki warna dasar yang kurang menarik, ketika ditempatkan atau ditawarkan pada waktu yang bersamaan maka wistawan akan lebih cenderung mengambil paket wisata dengan warna dasar menarik tersebut dan kemungkinan untuk menjadi pilihan wisatawan untuk dibeli menjadi lebih besar.
Penampilan pramuwisata dapat menjadi salah satu faktor pemilihan sebuah paket wisata karena pada saat pramuwisata menawarkan paket wisata ini kepada wisatawan, apabila penampilan pramuwisata kurang menarik, tidak sopan dan tidak sesuai dengan SOP yang ditentukan dari perusahaan maka wisatawan akan cenderung tidak menghiraukan apapun yang disampaikan oleh pramuwisata tersebut, apabila hal ini terjadi maka jenis paket apapun tidak akan dapat terjual, namun sebaliknya apabila pramuwisata memiliki penampilan yang menarik, sopan dan sesuai dengan SOP perusahaan maka ini akan menjadi daya tarik tersendiri untuk lebih mudah menjual paket wisata tersebut kepada wisatawan.

\section{SIMPULAN DAN SARAN}

Dari 21 indikator yang diasumsikan mempengaruhi pemilihan paket wisata Kintamani - Monkey Forest Tour tersisihkan sebanyak 3 variabel kemudian menyisakan 18 variabel yang membentuk 5 faktor yang paling mempengaruhi pemilihan paket wisata Kintamani - Monkey Forest Tour oleh wisatawan, lima faktor tersebut antara lain :

1. Faktor Harga terdiri dari variabel variasi obyek $(0,658)$, waktu yang ditawarkan $(0,651)$, harga yang ditawarkan $(0,594)$, harga termasuk tiket masuk $(0,714)$, harga termasuk asuransi $(0,531)$, harga termasuk snack $(0,627)$, harga termasuk makan siang $(0,819)$, desain brosur $(0,596)$, terdapat peta pada brosur $(0,731)$, dan informasi yang lengkap pada brosur $(0,733)$.

2. Faktor Icon Paket Wisata terdiri dari variabel kecakapan pramuwisata $(0,860)$, dan icon paket berupa gambar Gunung Batur $(0,842)$.

3. Faktor Transportation terdiri dari variabel kendaraan sesuai yang diinginkan (0,693), penjemputan ke 
hotel $(0,624)$, dan tempat makan siang yang menarik $(0,743)$.

4. Faktor Tampilan Brosur terdiri dari variabel brosur memiliki warna yang menarik (0,783), dan gambar depan brosur menarik $(0,694)$.

5. Faktor Penampilan Pramuwisata terdiri dari variabel penampilan pramuwisata $(0,852)$

Dengan memperhatikan faktor - faktor yang terbentuk tersebut hendaknya Destination Asia bisa menjadikan hasil penelitian ini sebagai sebuah acuan dan pertimbangan dalam hal baik perbaikan sebuah paket wisata yang telah ada maupun untuk membuat sebuah paket wisata yang baru. Dalam penelitian ini juga ditemukan tiga variabel dengan nilai loading yang lemah, hal ini berarti variabel ini perlu diperhatikan untuk lebih ditingkatkan lagi, tiga variabel tersebut diantaranya wawasan pramuwisata, fasilitas kendaraan, dan fasilitas restaurant.

\section{Saran}

Hasil dari penelitian ini merupakan faktor-faktor internal sebuah paket wisata yang merupakan aspek-aspek/unsur-unsur yang diharapkan oleh wisatawan, maka dari itu penelitian ini diharapkan dapat menjadi sebuah acuan dan gambaran untuk melakukan penelitian lanjutan yang dapat berupa sebuah penelitian mengenai pengemasan paket wisata di suatu daerah yang memiliki potensi dan daya tarik wisata, dan dapat juga menjadi referensi bagi penelitian-penelitan selanjutnya yang relevan dengan penelitian ini.

\section{DAFTAR PUSTAKA}

Afriani, Ika Dyah. 2015. Maskot Prajurit Nyutro Sebagai Branding Paket Wisata Kerajinan PT. Mitra Persada Travelindo Yogyakarta. Laporan Skripsi. Fakultas Bahasa dan Seni Universitas Negeri Yogyakarta.
Fiatiano, Edwin. 2004. Perencanaan Paket Wisata atau Tur. Surabaya: Jurnal.

Permana, Bagus Fuad. 2009. Perancangan Media Promosi Wana Wisata Tanjung Papuma Jember. Surabaya: jurnal.

Sukandarrumidi. 2006. Metodologi Penelitian Petunjuk Praktis Untuk Peneliti Pemula. Yogyakarta: Gajah Mada University Press.

Suwena. 2010. Pengetahuan Dasar Imu Pariwisata. Denpasar : Udayana University Pers.

Widyasrama, I B Made. 2014. Pengaruh Brand Image dan Received Quality terhadap Pengambilan Keputusan Wisatawan dalam Pembelian Produk Watersport di Tanjung Benoa. Laporan Skripsi. Fakultas Pariwisata Universitas Udayana.

www.disparda.baliprov.go.id. Di akses pada tanggal 11 juli 2015. 